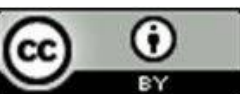

\title{
CHARACTERISTICS OF MENINGOCOCCAL INFECTION MORBIDITY IN THE REPUBLIC OF MOLDOVA OVER THE PERIOD 2000-2019
}

\section{Victoria BUCOV ${ }^{1}$, Alexei CEBAN ${ }^{1}$, Ludmila BIRCA ${ }^{2}$}

${ }^{1}$ National Agency for Public Health, Chisinau, Republic of Moldova

2MSPI, Municipal Clinical Children's Hospital of Infectious Diseases, Chisinau, Republic of Moldova

Corresponding author: Victoria Bucov, e-mail: v.e.bucova@gmail.com

DOI: $10.38045 /$ ohrm.2020.1.12

UDC: $616.98: 579.845(478)$

Keywords: meningo- Introduction. Meningococcal infection (MI) and N. meningitidis carriage are widespread. coccal infection, The global incidence represents a total of 500,000-1,200,000 cases per year, of which epidemiology, mor- 50,000-135,000 are fatal. In European countries the incidence is 0.6-2.0 per 100,000. bidity. Infants and young people are more likely to get affected due to different genotypes of meningococci. Thus, MI surveillance is required.

Material and methods. The research purpose was to perform an epidemiological analysis of MI in the Republic of Moldova between 2000 and 2019. In the descriptive retrospective epidemiological study were analysed the total MI incidence of a population of 100,000 people, the number of cases in urban and rural areas, the morbidity rate among 1000 children aged between 0 and 17 years, and patients' age structure.

Results. A decreased incidence, without cyclicity, was registered over the past 5 years from 2.57 to 0.55-1.01 per 100,000. The number of carriers accounted for 0.48-0.26 per 100,000 between 2000 and 2005, and zero during 2016-2019. MI vaccination is not carried out. The MI incidence in urban and rural areas was the same. In children aged between 0 and 17 years, during 2000 and 2005, MI incidence was 0.05-0.07, compared to 2016-2019 when it constituted 0.02-0.04 per 1000. In children aged between 0 and 2 years these indices were 0.08 per 1000 in 2004, and 0.44 per 1000 in 2018. Thus, the indices were lower among children aged between 3 and 6 years.

Conclusions. Incomplete detection of MI has been noted. Children aged between 0 and 2 years are prone to develop MI, the most vulnerable ones being children aged up to one year. The age structure of patients depends on the intensity of the epidemic process. Hence, it is necessary to improve MI surveillance with genotyping of circulating strains.

Cuvinte cheie: infecție meningococică, epidemiologie, morbiditate.

\section{PREZENTARE GENERALĂ A ASPECTELOR CARACTERISTICE ALE MORBIDITĂTII PRIN} INFECTIIA MENINGOCOCICĂ ÎN REPUBLICA MOLDOVA ÎN PERIOADA ANILOR 2000-2019 Introducere. Infecția meningococică (IM) și portaj de N. meningitidis sunt larg răspândite, incidența globală fiind de 500.000-1.200.000 cazuri anual; 50.000-135.000 dintre ele sunt fatale; în țările europene incidența este de 0,6-2,0 la 100.000. Cei mai afectați sunt sugarii, adolescenții și adulții tineri. Din cauza variațiilor genetice ale meningococilor, este necesară o supraveghere permanentă a IM.

Material și metode. Scopul lucrării - analiza epidemiologică a IM în Republica Moldova în aa. 2000-2019. În cadrul studiului descriptiv-retrospectiv epidemiologic au fost analizate morbiditatea generală prin IM la 100 mii populație, numărul de cazuri atestate în zonele urbane și în cele rurale, rata morbidității, înregistrate pe un eșantion de 1000 de copii, având vârsta de 0-17 ani și structura de vârstă a bolnavilor.

Rezultate. Este evidentă diminuarea aciclică a morbiditătii, de la 2,57 la 100 mii populație, până la 0,55-1,01 în ultimii 5 ani. Numărul purtătorilor în 2000-2005 era 0,48-0,26 la 100 mii, și zero în 2016-2019. Vaccinarea împotriva IM nu se realizează. Intensitatea IM în zonele urbane și în cele rurale este la același nivel. La copiii de 0-17 ani, IM era de 0,050,07 în 2000-2005 și de 0,02-0,04 la 1000 copii în 2016-2019; la cei de 0-2 ani era de la 0,44 în 2004 și de la 0,08 la 1000 în 2018. La copiii de 3-6 ani este o incidență mai joasă.

Concluzii. Se constată evidențierea incompletă a IM. Cei mai afectați sunt copiii de 0-2 ani, în special cei de până la un an. Structura de vârstă a bolnavilor depinde de intensitatea proceslui epidemic. Se impune perfecționarea sistemului de supraveghere a IM cu genotiparea tulpinilor circulante. 


\section{INTRODUCTION}

Meningococcal infection (MI) caused by Neisseria meningitidis bacterium, at least 13 genotypes, as well as the asymptomatic carriage of the causative agent, are widespread throughout the world. The distribution of meningococcal serogroups varies according to world regions (1-4). The overall incidence of invasive meningococcal disease varies between 500,000 and $1,200,000$ cases each year; of which, from 50,000 to 135,000 cases are fatal (5). In the European countries, the overall MI notification rate is from 0.6 to 2.0 per 100,000 people and varies in different regions. For example, in 2016, 3280 confirmed cases of invasive meningococcal disease, including 304 deaths, were reported in 30 EU Member States. In some countries the epidemiological situation of MI is quite dramatic, such as the tenfold increase in MenW type IM in the United Kingdom, recorded between 2009-2010 - 2016-2017 (6). Serogroups B and C are the most common causes of MI in Europe, but an increase in serogroup W has been observed in recent years. Generally, serogroup B causes the highest burden in Europe, followed by serogroups $C, W$ and $Y(1,7)$.

Nasopharyngeal colonization with Neisseria meningitidis ranges from $5-10 \%$ to $25 \%$ in certain populations (the highest is found in adolescents and closed groups). Invasive meningococcal disease is a major cause of meningitis and septicemia. It often has a rapid evolution, with a ratio of $8-15 \%$ case-fatality. Some age groups are disproportionately affected by MI, with major incidence peaks occurring in infants, adolescents, and young adults $(1,2,3,8)$.

In recent years within the Global Meningococcal Initiative (GMI), the global importance of meningococcal disease, the ever-changing epidemiology, and the importance of proper surveillance of this evidence-based disease have been emphasized. Due to large geographical variations of circulating meningococcal serogroups, each country should be further monitored in order to change major disease-causing serogroups, as well as to spread information on vaccination and control policies. Likewise, the laboratory capacity must be properly adapted to better understand local epidemiology and disease burden, as well as its impact (9-12).

Inactivated meningococcal vaccines are authorized. There are conjugate polysaccharide and po- lysaccharide vaccines containing capsules of serotypes A, C, Y and W. Antibiotics are used to eliminate infection transmission and to treat the disease $(1,2,3)$.

It can be concluded that analysis of epidemiological data on MI in different regions is necessary and relevant for a multilateral assessment. Such analyses have not been performed, which makes prevention difficult. The ongoing surveillance of MI is important for the development of future vaccination and surveillance policies.

\section{MATERIAL AND METHODS}

The purpose of the research is to analyze the epidemiological data collected in the Republic of Moldova over a period of about 20 years (20002019 ) in order to estimate the incidence and characteristics of meningococcal infection. In order to reveal the problems related to meningococcal infection worldwide, 212 bibliographic sources were analyzed as well as the WHO, CDC, ECDC materials published in the last five years.

The analysis of meningococcal infection morbidity in the Republic of Moldova over the period 2000-2019 was performed in the descriptive retrospective epidemiological study based on official statistical data (F.2) with the presentation of intensive and extensive indices, such as general morbidity per 100 thousand people (population), number of cases in urban and rural areas, morbidity of children aged 0-17 years by age groups per 1000 children, age structure of patients (\%), including adults, children up to one year, $0-2 ; 3-6 ; 7-17$ years. There were analyzed MI cases of 71 patients hospitalized over the period 2010-2019 in the Municipal Clinical Children's Hospital of Infectious Diseases.

\section{RESULTS}

The statistical data on the spread of meningococcal infection in the Republic of Moldova before 2000, revealed that between 1945 and1969 the morbidity on average was recorded at 0.98 cases per 100,000 people, between 1970 and 1989 it considerably increased (220-230 times compared to 1963). Over the period 1990-1999, 2-4 cases per 100,000 people were registered (13, 14). Vaccination against meningococcal infection is neither included in the National Immunization Program, nor carried out. 


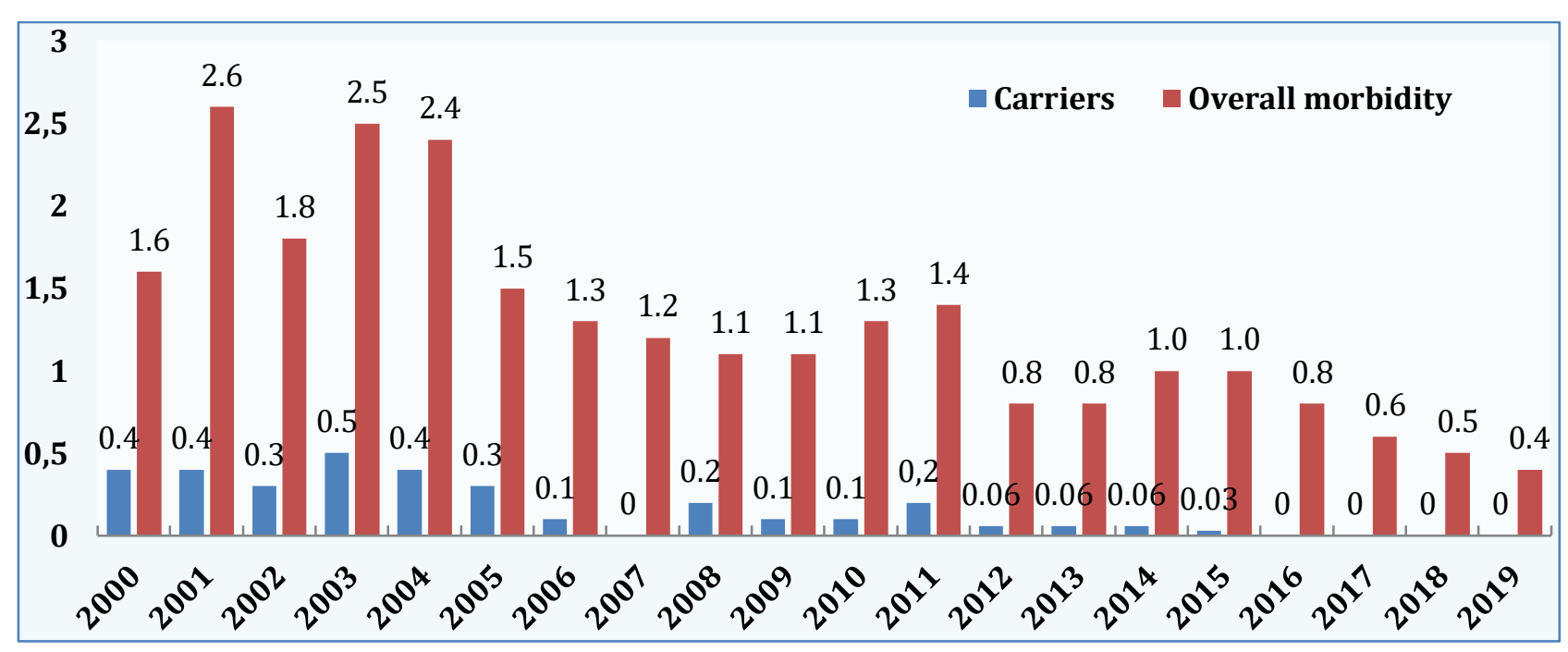

Figure 1. Data on the evolution of meningococcal infection morbidity and the level of N. meningitidis carriage, Republic of Moldova, 2000-2019.

Analysis of morbidity indices of meningococcal infection during the reference period found (fig.1) a gradual decrease from 2.57 to 100 thousand people (111 cases) at the beginning of the period, up to $0.55-1.01$ over the last 5 years (on average 23.6 cases per year). Analysis of multi- annual morbidity of meningococcal infection did not highlight any cyclicity. The number of $N$. meningitidis carriers over the period 2000-2005 accounted for $0.48-0.26$ per 100 thousand people (14.5 cases on average annually), then suddenly decreased to 0 (zero) during 2016-2019.

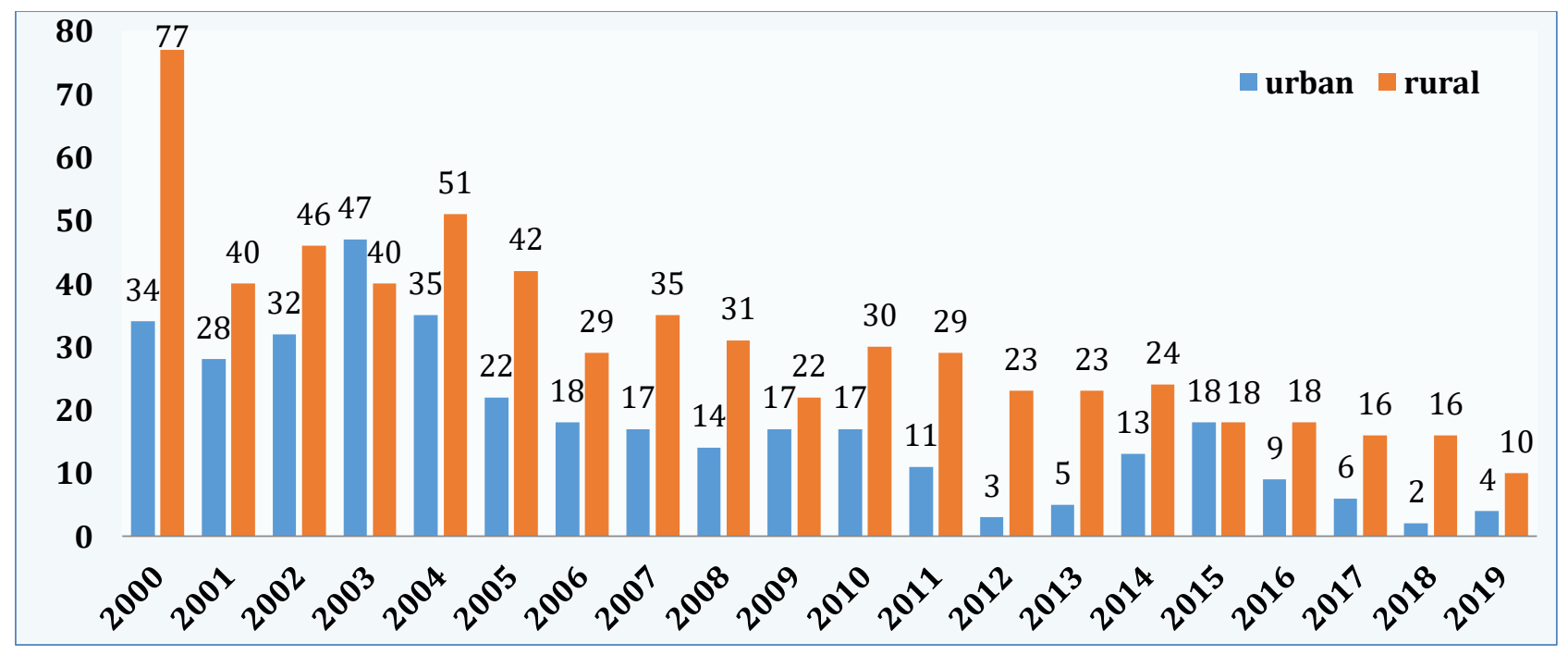

Figure 2. Data on the number of cases of meningococcal infection in urban and rural areas, Republic of Moldova, 2000-2019.

The data presented in Figure 2 show that the ratio of the number of cases of meningococcal infection in rural and urban areas ranges between 0 and 8 (2015 and 2018). The average annual ratio of cases of meningococcal infection in rural and urban areas is equal to 2.54 , which broadly reflects the ratio of the population in these two regions.
In order to take adequate surveillance and control measures of meningococcal infection, it is important to analyze how frequently and intensively different age groups of the population are affected, considering the fact that according to multiple scientific publications a higher incidence is observed in infants, adolescents, and young adults $(1,2,3,8,13)$. The data recorded in 
the Republic of Moldova during the reference period are presented in Figure 3.

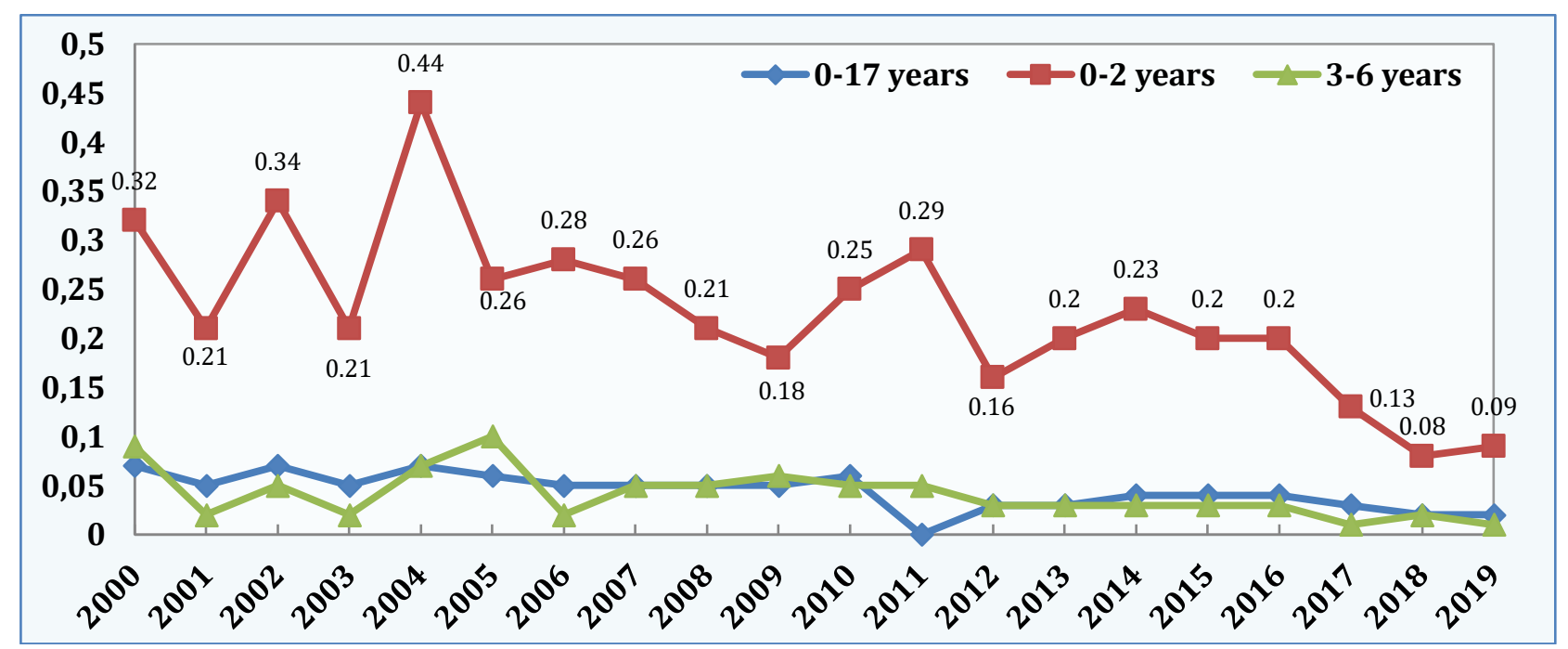

Figure 3. Data on meningococcal infection morbidity in children of different ages, Republic of Moldova, 2000-2019.

Data presented in Fig. 3 show that the morbidity of meningococcal infection in children aged between 0 and 17 years was $0.05-0.07$ per 1000 children over the period 2000-2005 and 0.020.04 per 1000 children over the period 20162019. The morbidity level in children aged be- tween 0 and 2 years ranged from 0.44 to 1000 children in 2004 and 0.08 to 1000 children in 2018. In children aged 3-6 years there was a lower incidence, 0.01 per 1000 children over the period 2017-2019 and 0.1 per 1000 children in 2005.

Table 1. Age distribution of MI patients in the Republic of Moldova, 2000-2019.

\begin{tabular}{cccccccc}
\hline \multirow{2}{*}{ Period } & \multirow{2}{*}{$\begin{array}{c}\text { Total } \\
\text { number } \\
\text { of cases }\end{array}$} & \multirow{2}{*}{$\begin{array}{c}\text { Average num- } \\
\text { ber of cases } \\
\text { per year }\end{array}$} & adults & & \multicolumn{4}{c}{ Average age rate of MI patients (\%) per year } \\
\cline { 5 - 8 } & & & & & \multicolumn{4}{c}{ children's age, years } \\
\cline { 5 - 8 } & & 86 & 27.4 & 72.6 & $\begin{array}{c}0-2 \text { (includ- } \\
\text { ing < 1 year) }\end{array}$ & $3-6$ & $7-17$ \\
\hline $\mathbf{2 0 0 0 - 2 0 0 4}$ & 430 & 49.4 & 9.7 & 90.3 & $53.3(17.9)$ & 12.1 & 17.3 \\
\hline $\mathbf{2 0 0 5 - 2 0 0 9}$ & 247 & 35.4 & 5.6 & 94.4 & $71.7(20.2)$ & 17.8 & 17.0 \\
\hline $\mathbf{2 0 1 0 - 2 0 1 4}$ & 177 & 23.6 & 8.5 & 91.5 & $64.4(32.2)$ & 14.2 & 8.5 \\
\hline $\mathbf{2 0 1 5 - 2 0 1 9}$ & 118 & & & & & &
\end{tabular}

Age structure analysis of patients with meningococcal infection (tab. 1) shows that among the total number of patients the disease predominated in children $72.6-94.4 \%$, in different periods. The rate of children aged between 0 and 2 years was the highest compared to other age groups, being within $43.3 \%$ in the first period and 94.4\% during 2010-2014. Particular attention was drawn to children up to one year that constituted a rather large number among patients with meningococcal infection; the rate ranged from $17.9 \%$ in the first period and $32.2 \%$ in the last one. The epidemic incidence, with expressed intensity, was higher among adult patients, $27.4 \%$ during 2000-2004, compared to
$5.6 \%-9.7 \%$ in other researched periods.

During 2010-2019, in the Municipal Clinical Children's Hospital of Infectious Diseases in Chisinau, 71 patients with meningococcal infection were admitted $23.3 \%$ of the total number of patients - 305 people). Annually, the number of children hospitalized with MI fluctuated, 10-16 patients per year (44.8-71.7\% of the total number of patients) during 2010-2015 and 2-4 per year (7.4-14.8\% of the total number of patients) during 2016-2019. Respectively, MI share was $0.02-0.2 \%$ per hospitalized patients. All patients developed meningococcemia, a severe form of MI; about $75 \%$ had purulent meningitis, of which over $2 / 3$ of cases had toxic shock syndrome and/ 
or cerebral edema. Four children died (5.6\%), all of them being up to 1 year old. The etiological diagnosis in most cases was assessed according to clinico-epidemiological pattern. As a result, the bacteriological examination (CSF, blood and nasopharynx exudate) was negative. In 2019, in two cases, of the total number of 3 children with MI, Neisseria meningitidis DNA in CSF was detected using PCR.

\section{DISCUSSIONS}

During the researched period, 2000-2019, in the Republic of Moldova due to the absence of MI vaccines there was a gradual decrease in morbidity of this infection (on average 23.6 cases per year) without obvious cyclicity. The number of $N$. meningitidis carriers dropped to 0 (zero) in the last three years. It is known that on average 1\% to $10 \%$ of the population are asymptomatic carriers of meningococci, but in epidemic situations this rate ranges between $10 \%$ and $25 \%(1,14)$. This accounts for the incomplete recording of Neisseria meningitides cases and its carriers. In addition, it is known that different age groups are disproportionately affected by MI, with major incidence peaks occurring in infants, adolescents and young adults $(1,2,3,8)$. In the Republic of Moldova, according to the analysed data, there is only one, so-called epidemic peak, in children aged between 0 and 2 years, except for adolescents and young adults.

It should be noted that IM surveillance is necessary to reduce the impact of meningococcal disease, monitor morbidity incidence and prevent epidemics. This practice should include detection, application of evidence-based measures, and etiological investigation of each suspected case of meningococcal disease. In addition, modern surveillance includes the identification of circulating serogroups of $N$. meningitidis, this being the first step in implementing strategies to prevent MI by vaccination (1-3). These principles formulated by WHO and Global Meningococcal Initiative specialists should be laid on the organization of meningococcal infection surveillance in the Republic of Moldova.

\section{CONCLUSIONS}

1. Based on the data analysis related to morbidity of meningococcal infection and the number of N. meningitidis carriers, an incomplete highlighting of the affected persons was found.

2. Children aged between 0 and 2 years, especially infants up to one year, are most affected by meningococcal infection.

3. The age structure of patients with meningococcal infection depends on the epidemic process intensity. Thus, due to progressive involvement, there might occur a higher morbidity rate among adolescents and adults.

4. In the Republic of Moldova, it is necessary to improve the surveillance and control of meningococcal infection as well as to carry out the permanent examination of circulating N. meningitides strains, including genotyping.

\section{CONFLICT OF INTERESTS}

No conflicts of interest were reported.

\section{REFERENCES}

1. ECDC. Factsheet about meningococcal disease. Available from: https://www.ecdc.europa.eu/ en/meningococcal-disease/factsheet [Accessed 2th March 2020].

2. Borrow R, Alarcón P, Carlos J, et al. The Global Meningococcal Initiative: global epidemiology, the impact of vaccines on meningococcal disease and the importance of herd protection. Expert Rev Vaccines. 2017;16(4):313-328.

3. Acevedo R, Bai X, Borrow R, et al. The Global Meningococcal Initiative meeting on prevention of meningococcal disease worldwide: Epidemiology, surveillance, hypervirulent strains, antibiotic resistance and high-risk populations. Expert Rev Vaccines. 2019;18(1):15-30.

4. Caugant DA, Brynildsrud OB. Neisseria meningitidis: using genomics to understand diversity, evolution and pathogenesis. Nat Rev Microbiol. 2020;18(2):84-96.

5. Hennadii M. Multiple Linear Regression Model of Meningococcal Disease in Ukraine: 1992-2015. Comput Math Methods Med. 2020;20:510-512. doi:10.1155/2020/5105120

6. Laboratory confirmed cases of IMD England data tables 2017 to 2018. Available from: https://assets.publishing.service.gov.uk/governm ent/uploads/system/uploads/attachment_data/fil e/752085/ [Accessed 2th March 2020]. 
7. Krone M, Gray S, Abad R, et al. Increase of invasive meningococcal serogroup W disease in Europe, 2013 to 2017. Euro Surveill. 2019;24(14).

8. Presa J, Findlow J, Vojicic J, Williams S, Serra L. Epidemiologic Trends, Global Shifts in Meningococcal Vaccination Guidelines, and Data Supporting the Use of MenACWY-TT Vaccine. A ReInfect Dis Ther. 2019;8(3):307-333. doi: 10.1007/ s40121-019-0254-1

9. Purmohamad A, Abasi E, Azimi T, et al. Global estimate of Neisseria meningitidis serogroups proportion in invasive meningococcal disease: A systematic review and meta-analysis. Microb Pathog. 2019;134:103571.

10. Heidi M. Soeters, Lucy A. McNamara, Amy E. Blain, et al. University-Based Outbreaks of Meningococcal Disease Caused by Serogroup B, United States,
2013-2018. Emerg Infect Dis. 2019;25(3):434440.

11. Peterson ME, Li Y, Bita A, et al. Meningococcal serogroups and surveillance: a systematic review and survey. J Glob Health. 2019;9(1):010409.

12. Booy R, Gentile A, Nissen M, Whelan J, Abitbol V. Recent changes in the epidemiology of Neisseria meningitidis serogroup $\mathrm{W}$ across the world, current vaccination policy choices and possible future strategies. Hum Vaccin Immunother. 2018;15:470480.

13. Rusu G, Manic L. Infecţia meningococică la copil. Protocol clinic naţional PCN-6 [Meningococcal infection in children. National clinical protocol PCN6]. Chisinau, 2017.

14. Prisacaru V. Epidemiologie speciala [Special epidemiology]. Chisinau, 2015. 